\title{
Simple estimate of creatinine clearance from plasma creatinine in neonates
}

\author{
G ZACCHELLO, M BONDIO, O S SAIA, G LARGAIOLLI, R VEDALDI, AND \\ F F RUBALTELLI
}

Department of Paediatrics, University of Padua, and Institute of Statistics, Padua, Italy

SUMMARY Thirteen newborn infants, 8 preterm and 5 term, with either mild or serious neonatal asphyxia were studied. From the first 24 hours of life to day 13, glomerular filtration rate (GFR) estimated by creatinine clearance was compared with the values obtained using Schwartz's formula: GFR $\left(\mathrm{ml} / \mathrm{min}\right.$ per $\left.1.73 \mathrm{~m}^{2}\right)=0.55 \times$ length $(\mathrm{cm}) /$ plasma creatinine $(\mathrm{mg} / 100 \mathrm{ml})$. Both in term and preterm infants, values of formula-calculated creatinine clearance were slightly higher than values obtained by the classical method; nevertheless the data show significant correlations, respectively $r=0.867$ and $r=0.795(P<0.001)$. This formula provides an adequate estimation of neonatal creatinine clearance (a marker for GFR) directly from plasma creatinine provided that body length is taken into consideration. The necessity for urine collection and the associated problems are thus obviated. The simplicity of Schwartz's formula permits easy monitoring of renal function, especially in neonatal asphyxia in which the risk of developing renal failure is great.

It has been shown that endogenous creatinine clearance provides an adequate estimation of inulin clearance, as a marker for glomerular filtration rate (GFR) in low birthweight infants between the 1st and 10th days of age. ${ }^{1}$ Tubular secretion of creatinine and plasma chromogens, including bilirubin, interfere with the accuracy but not with the reliability of endogenous creatinine clearance; nevertheless in clinical practice creatinine clearance remains the most commonly used laboratory assessment of glomerular function in neonates, despite methodological and technical problems of urine collection. ${ }^{2-5}$

In 1979 Fawer et al. ${ }^{6}$ compared single injection clearance of inulin with the standard clearance in neonates aged between 1 and 20 days. They concluded that one should be cautious when interpreting results obtained by the single injection technique during the immediate postnatal period, even though this method has the advantage that it does not require urine collection.

Schwartz et al. ${ }^{7}$ in 1976 , reported that an accurate estimate of GFR could be obtained from the simple determinations of plasma creatinine $\left(P_{c}\right)$ and body length (l). An empirical formula derived by Schwartz in a study on infants aged at least 6 months can then be applied:

GFR $\left(\mathrm{ml} / \mathrm{min}\right.$ per $\left.1.73 \mathrm{~m}^{2}\right)=0.55 \pm 1(\mathrm{~cm}) / \mathrm{Pc}$ $(\mathrm{mg} / 100 \mathrm{ml})$.

Analogous conclusion was reported in 1976 by
Counahan et al. ${ }^{8}$ who used a different constant. The discrepancy between the constant of Counahan and that of Schwartz, respectively 0.43 and 0.55 , is not substantial in our opinion and may be explained as follows. For Schwartz $(0.55)$ the $P_{c}$ is represented by a total value while for Counahan $(0.43)$ the $P_{c}$ is a real value which does not include the non-creatinine chromogens. ${ }^{7-9}$ In 1977 Szelid and Méhes ${ }^{10}$ confirmed Counahan's data but did not recommend the use of the formula for infants aged less than 1 year; for them 24-hour creatinine clearance was preferred, despite the difficulties in collecting urine.

The purpose of our investigation is to compare neonatal GFR estimated by creatinine clearance with that calculated by Schwartz's formula.

\section{Materials and methods}

The subjects of this study were 13 newborn infants admitted to our neonatal intensive care unit for neonatal asphyxia. Eight were preterm (Table 1), of whom one died on day 9 because of bilateral pneumothorax; 5 were born at term (Table 2).

Depending on the degree of fetal distress determined by the presence, after resuscitation, of respiratory distress, transient cardiomegaly, or cerebral irritation, each infant was designated as having either mild asphyxia at birth or serious postasphyxia syndrome. Infants with serious 
Table 1 Clinical data for 8 ( 4 boys and 4 girls) preterm infants (gestational age $\leqslant 37$ weeks)

\begin{tabular}{llll}
\hline & $\begin{array}{l}\text { Gestational } \\
\text { age }(\text { weeks })\end{array}$ & $\begin{array}{l}\text { Birthweight } \\
(\mathrm{g})\end{array}$ & $\begin{array}{l}\text { Birth length } \\
(\mathrm{cm})\end{array}$ \\
\hline Mean (SD) & $33 \cdot 5(3 \cdot 1)$ & $1604(487)$ & $\begin{array}{l}40 \cdot 7(3 \cdot 7) \\
37-48\end{array}$ \\
Range & $28-37$ & $1030-2500$ & $37-400$ \\
\hline
\end{tabular}

Table 2 Clinical data for 5 ( 4 boys and 1 girl) term infants (gestational age $>37$ weeks)

\begin{tabular}{|c|c|c|c|}
\hline & $\begin{array}{l}\text { Gestational } \\
\text { age (weeks) }\end{array}$ & $\begin{array}{l}\text { Birthweight } \\
(\mathrm{g})\end{array}$ & $\begin{array}{l}\text { Birth length } \\
(\mathrm{cm})\end{array}$ \\
\hline $\begin{array}{l}\text { Mean (SD) } \\
\text { Range }\end{array}$ & $\begin{array}{l}39 \cdot 4(1 \cdot 2) \\
37 \cdot 5-40 \cdot 5\end{array}$ & $\begin{array}{l}3518(500) \\
2650-3900\end{array}$ & $\begin{array}{l}51 \cdot 6(2 \cdot 4) \\
49-55\end{array}$ \\
\hline
\end{tabular}

postasphyxia were evaluated on the $1 \mathrm{st}, 2 \mathrm{nd}$, $3 \mathrm{rd}$, 5th, 10th, and 13th days of life and those with mild asphyxia were evaluated on the 1 st, 2 nd, 5 th, and 10th days of life. Altogether 66 estimations were carried out. Accurate 24-hour urine samples were collected on these days and the plasma creatinine $\left(P_{c}\right)$ and the creatininuria $\left(\mathrm{C}_{\mathrm{u}}\right)$ were determined by means of the Technicon automatic method, which measures the creatinine total value. ${ }^{11}$

Body surface was calculated from body weight using Vaughan's formula: body surface $\left(\mathrm{m}^{2}\right)=$ $(0.05 \times \mathrm{kg})+0.05$. This formula is applicable for a range of body weight from 1 to $5 \mathrm{~kg} .{ }^{12}$

Endogenous creatinine clearance was calculated by the formula UV/P and the result was related to $1.73 \mathrm{~m}^{2}$ of body surface. The values were then compared with those estimated by Schwartz's formula: GFR $\left(\mathrm{ml} / \mathrm{min}\right.$ per $\left.1.73 \mathrm{~m}^{2}\right)=0.55 \times 1$ $(\mathrm{cm}) / P_{c}(\mathrm{mg} / 100 \mathrm{ml})$. On the above days, the crown-to-heel length was measured with a neonatometer using the method of Davies and Holding. ${ }^{13} 14$

\section{Results}

As shown (Table 3) for both preterm and term

Table 3 Means and standard deviations of 24-hour creatinine clearance $\left(\mathrm{ml} / \mathrm{min}\right.$ per $\left.1.73 \mathrm{~m}^{2}\right)$ and

Schwartz's formula estimated values

$0.55 \times$ length $(\mathrm{cm}) /$ plasma creatinine $(\mathrm{mg} / 100 \mathrm{ml})$

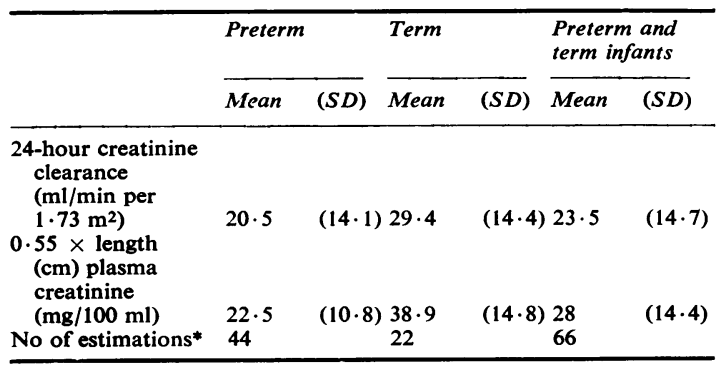

*Between first 24 hours and 30th day of life.
Table 4 Relationship between $G F R=24$-hour creatinine clearance ( $\mathrm{ml} / \mathrm{min}$ per $\left.1.73 \mathrm{~m}^{2}\right)$ and GFR as predicted by Schwartz's formula $0.55 \times l(\mathrm{~cm}) / \mathbf{P}_{\mathrm{c}}$ ( $\mathrm{mg} / 100 \mathrm{ml}$ ) in preterm and term infants. Values are treated logarithmically

\begin{tabular}{lcc}
\hline & Preterm infants & Term infants \\
\hline $\begin{array}{l}\text { No of } \\
\text { estimations* }\end{array}$ & 44 & \\
Means X (SE) & $1.221(0.043)$ & $1.420(0.046)$ \\
Means Y (SE) & $1.309(0.029)$ & $1.559(0.036)$ \\
Y $=$ aX + b & $Y=0.54 X+0.65$ & $\mathrm{Y}=0.677 X+0.597$ \\
$\mathrm{r}$ & 0.795 & 0.867 \\
$\mathrm{P}$ & $<0.001$ & $<0.001$ \\
$\mathrm{~s}^{2}$ & 0.0143 & 0.0074 \\
\hline
\end{tabular}

* Between first 24 hours and 30th day of life.

$X=\log 24$-hour creatinine clearance values $\left(\mathrm{ml} / \mathrm{min}\right.$ per $\left.1.73 \mathrm{~m}^{2}\right)$.

$\mathrm{Y}=\log$ formula estimated values $0.55 \times 1(\mathrm{~cm}) / \mathrm{P}_{\mathrm{c}}(\mathrm{mg} / 100 \mathrm{ml})$.

$\mathrm{SE}=$ standard errors (means $\mathrm{X}$ or means $\mathrm{Y}$ )

$\mathbf{Y}=\mathbf{a X}+\mathbf{b}$ regression line.

a $=$ regression coefficient; $\mathbf{b}=$ intercept.

$\mathbf{r}=$ correlation coefficient

$\mathbf{s}^{2}=$ residual variances.

Table 5 Means, standard errors, and probability values for differences from zero of $d A$ and $d B$. Variance of $d A$ and $d B$

\begin{tabular}{llllll}
\hline Infants & $n$ & $\bar{d} A$ or $\bar{d}^{B}$ & $S E(\bar{d})$ & $P$ & $V$ \\
\hline Preterm & 44 & -0.089 & 0.027 & $<0.001$ & 0.0314 \\
Term & 22 & -0.146 & 0.021 & $<0.001$ & 0.0098 \\
\hline
\end{tabular}

$\mathrm{dA}=\log 24$-hour creatinine clearance values $-\log \left(0.55 \times 1 / \mathrm{P}_{\mathrm{c}}\right)$ formula estimated values in preterm infants.

$\mathrm{dB}=\log 24$-hour creatinine clearance values $-\log \left(0.55 \times 1 / \mathrm{P}_{\mathrm{o}}\right)$ formula estimated values in term infants.

$\bar{d} A, \bar{d} B=$ means of $\mathrm{dA}$ and $\mathrm{dB}$.

SE $(\bar{d})=$ standard errors $(\bar{d} A$ or $\bar{d} B)$.

$\mathrm{V}=$ variance $(\mathrm{dA}$ or $\mathrm{dB})$.

infants, the average value for 24-hour creatinine clearance determinations is lower than the value found by Schwartz's formula. Values of formulacalculated creatinine clearance are higher than values obtained by the classical method, particularly for term infants; nevertheless the values show significant correlations. Our statistical analysis of the data, logarithmically treated to normalise the distributions, is shown in Tables 4 and $5 .{ }^{15}$ The correlation between the two methods is significant for preterm infants: $\mathrm{r}=0.795(\mathrm{P}<0.001)$ and improves still more for term ones: $r=0.867(P<0.001)$ (Figure). Mean and variances of individual logarithmic differences between 24-hour creatinine clearance and formula calculated creatinine clearance show constant and significant overestimation for the formula values in 21 out of 22 term infants and in 32 out of 44 preterm ones. The means of $\mathrm{dA}=\log$ 24-hour creatinine clearance $-\log \left(0.55 \times 1 / \mathbf{P}_{c}\right)$ for preterm infants, and of $\mathrm{dB}=\log$ 24-hour creatinine clearance 


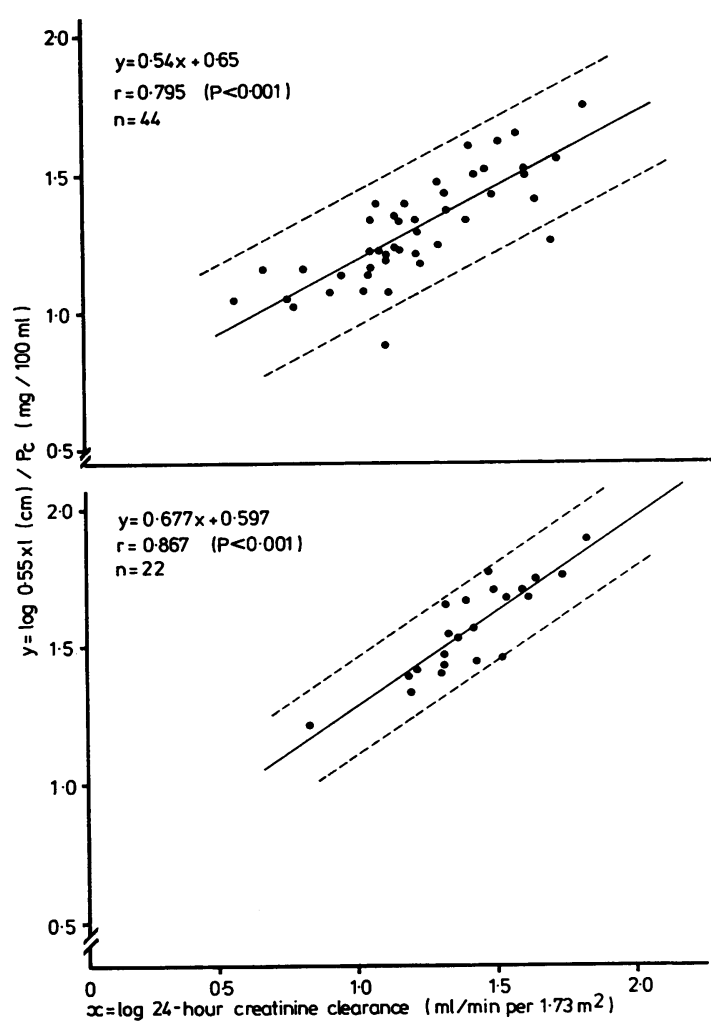

Figure Relationship between $G F R=24$-hour creatinine clearance ( $\mathrm{ml} / \mathrm{min}$ per $\left.1.73 \mathrm{~m}^{2}\right)$ and GFR as predicted by Schwartz's formula $0.55 \times l(\mathrm{~cm}) / P_{\mathrm{c}}$ ( $\mathrm{mg} / 100 \mathrm{ml}$ ). The data were treated logarithmically. The lines show the calculated regression line and the $95 \%$ confidence limits for predicted values. Upper portion shows preterm infants, lower portion term infants.

$-\log \left(0.55 \times 1 / \mathbf{P}_{c}\right)$ for term infants, differ significantly from zero confirming this overestimation. The variance of $\mathrm{dA}$, significantly larger than that of $\mathrm{dB}(\mathrm{P}<0.01)$, shows greater variability in preterm infants (Table 5).

\section{Discussion}

The results of this study demonstrate the suitability of Schwartz's formula for determining creatinine clearance (a marker for GFR) for both groups of newborn infants. This is noteworthy since the estimation of creatinine clearance by the classical method requires the collection of urine, at best a difficult task with neonates. In the past, Schwartz's formula has not been applied to so young an infant. Szelid and Méhes ${ }^{10}$ found that for infants aged less than 1 year, a low correlation coefficient existed between the classic 24 -hour creatinine clearance and the formula values. Their data however, are hard to justify as the age range they studied was too wide (1 month to 1 year) and the number of determinations too few (21).

Our results show that within 1-30 days of life creatinine clearance can be directly determined from plasma creatinine provided body length is taken into consideration: GFR $\left(\mathrm{ml} / \mathrm{min}\right.$ per $\left.1.73 \mathrm{~m}^{2}\right)=$ $0.55 \times 1(\mathrm{~cm}) / \mathrm{P}_{\mathrm{c}}(\mathrm{mg} / 100 \mathrm{ml})$.

In preterm infants, the slightly greater range of values can be reasonably explained by greater individual differences and by more frequent estimation errors. In our opinion the overestimation found in this study does not allow both methods to be used alternately in the same patient. In conclusion, renal function can be easily followed using Schwartz's formula especially in neonatal asphyxia where the risk of developing renal failure is great. Therefore, total plasma creatinine and body length permit a rapid, simple, but slightly higher estimation of creatinine clearance in preterm and term newborn infants, thus obviating the necessity for urine collection.

\section{References}

1 Stonestreet B S, Bell E F, Oh W. Validity of endogenous creatinine clearance in low birthweight infants. Pediatr Res 1979; 13: 1012-4.

2 Broberger U, Aperia A. Renal function in infants with hyperbilirubinemia. Acta Paediatr Scand 1979; 68: 75-9.

3 Sertel H, Scopes J. Rates of creatinine clearance in babies less than one week of age. Arch Dis Child 1973; 48: 717-20.

4 Sertel H. Letter: Rates of creatinine and urea clearance in pre-term infants on the third day after birth. Arch Dis Child 1974; 49: 79.

5 Gautier E. Evaluation of renal function. In: Klaus $\mathbf{M ~ H ,}$ Fanaroff A A, eds. Care of the high-risk neonate, second edition. Philadelphia: Saunders, 1979: 332.

6 Fawer C L, Torrado A, Guignard J P. Single injection clearance in the neonate. Biol Neonate 1979; 35: 321-4.

7 Schwartz G J, Haycock G B, Edelmann C M, Jr, Spitzer A. A simple estimate of glomerular filtration rate in children derived from body length and plasma creatinine. Pediatrics 1976; 58: 259-63.

8 Counahan R, Chantler C, Ghazali S, Kirkwood B, Rose F, Barratt T M. Estimation of glomerular filtration rate from plasma creatinine concentration in children. Arch Dis Child 1976; 51 : 875-8.

9 Goldsmith D I. Clinical and laboratory evaluation of renal function. In: Edelmann $\mathbf{C ~} \mathbf{M}, \mathrm{Jr}$, ed. Pediatric kidney disease. Vol. 1. Boston: Little Brown, 1978: 213-24.

10 Szelid Zs, Méhes K. Letter: Estimation of glomerular filtration rate from plasma creatinine concentration in children of various ages. Arch Dis Child 1977; 52: 669.

11 Technicon Instrument Company. Autoanalyst 1966; 1 : 89.

12 Vaughan V C. Growth and development. In: Nelson W E, ed. Textbook of pediatrics, eleventh edition. Philadelphia: Saunders, 1979: 10-46. 
13 Davies D P, Holding R E. Neonatometer: a new infant length measurer. Arch Dis Child 1972; 47: 938-40.

14 Cameron N. The methods of auxological anthropometry. In: Falkner F, Tanner J M, eds. Human growth: postnatal growth. Vol. 2. London: Baillière Tindall, 1978: 35-90.

15 Armitage P. Statistical methods in medical research. Milan: Feltrinelli, 1975: 149-67.
Correspondence to Dr G Zacchello, Department of Paediatrics, University of Padua, Via Giustiniani 3, I-35100 Padova, Italy.

Received 6 August 1981

\section{Referees 1981}

We continue to depend heavily on the help we get from our referees who assess and, in many cases, suggest significant improvements to the papers. This is the only opportunity we have to acknowledge publicly the work done by them during the past year.

G H Addison
P Aggett
D G Altman
Barbara M Ansell
G C Arneil
C C Bailey
N D Barnes
T M Barratt
A J Barson
J D Baum
P F Benson
A Bentovim
Margaret Borzyskowski
P T Bray
J T Brocklebank
C G D Brook
O G Brooke
J K Brown
I J Carré
F Carswell
C Chantler
Judith M Chessells
M L Chiswick
Barbara Clayton
F Cockburn
K W Cross
D P Davies
Pamela A Davies
J A Davis
P Dear
M Dillon
R Dinwiddie
J A Dodge
G Draper
S W D’Souza
J A Dudgeon
Maureen Duggan
P M Dunn
G J Ebrahim
R T D Emond

$\begin{array}{ll}\text { J N G Evans } & \text { I C S Normand } \\ \text { H R Gamsu } & \text { F O'Grady } \\ \text { J F T Glasgow } & \text { A D Patrick } \\ \text { D B Grant } & \text { B Payne } \\ \text { M H Hambling } & \text { J B Pearce } \\ \text { R B Harcourt } & \text { M Pembrey } \\ \text { J T Harries } & \text { M A Preece } \\ \text { D F N Harrison } & \text { H Pullen } \\ \text { G B Haycock } & \text { E O R Reynolds } \\ \text { L Hersov } & \text { R O Robinson } \\ \text { E N Hey } & \text { G W Rylance } \\ \text { J Hibbert } & \text { Jean Sands } \\ \text { R S Illingworth } & \text { B Sardharwalla } \\ \text { R S Jones } & \text { J K Sarsfield } \\ \text { I Kolvin } & \text { J W Scopes } \\ \text { J A Kuzemko } & \text { J E S Scott } \\ \text { H P Lambert } & \text { Olive Scott } \\ \text { R Lansdown } & \text { J C L Shaw } \\ \text { G H Lathe } & \text { E A Shinebourne } \\ \text { J S Lilleyman } & \text { H Simpson } \\ \text { M R Lee } & \text { Jean Smellie } \\ \text { M Levene } & \text { R W Smithells } \\ \text { R J Levinsky } & \text { B D Speidel } \\ \text { P D Lewis } & \text { T C B Stamp } \\ \text { J M Littlewood } & \text { L S Taitz } \\ \text { June K Lloyd } & \text { M S Tanner } \\ \text { J Lorber } & \text { J P M Tizard } \\ \text { Margaret Lynch } & \text { J H Tripp } \\ \text { F J Macartney } & \text { J A Walker-Smith } \\ \text { A S McNeish } & \text { J O Warner } \\ \text { Margaret Mearns } & \text { B A Wharton } \\ \text { C Metreweli } & \text { J White } \\ \text { A D Milner } & \text { R H R White } \\ \text { R D G Milner } & \text { J S Wigglesworth } \\ \text { R G Mitchell } & \text { G J Williams } \\ \text { Clare B Modell } & \text { M H Winterborn } \\ \text { D C Morley } & \text { C B S Wood } \\ \text { Patricia H Morris Jones } & \text { D G Young } \\ \text { A P Mowat } & \\ \text { B G R Neville } & \\ & \end{array}$

